\title{
Effect of putative probiont Enterococcus hirae on the hematological parameters of juvenile African catfish, Clarias gariepinus (Burchell, 1822) during pre- and post-challenge against Aeromonas hydrophila
}

\author{
Nur Hidayahanum Hamid a,b, Hassan Mohd Daud a, ${ }^{*}$, Prapansak Srisapoome ${ }^{\mathrm{b}}$, Hasliza Abu \\ Hassim $^{a}$, Md Sabri Mohd Yusoff a, Pattanapon Kayansamruaj ${ }^{b}$, Ruhil Hayati Hamdan ${ }^{c}$, Siti Fairus \\ Mohd Yusoff d, Siti Nadia Abu Bakar a
}

a Faculty of Veterinary Medicine, Universiti Putra Malaysia, 43400 UPM, Serdang, Selangor, Malaysia

${ }^{b}$ Faculty of Fisheries, Kasetsart University, Chatuchak, Bangkok 10900, Thailand

c Faculty of Veterinary Medicine, Universiti Malaysia Kelantan, 16100 Kota Bharu, Kelantan, Malaysia

${ }^{d}$ Faculty of Agriculture, Universiti Putra Malaysia, 43400 UPM, Serdang, Selangor, Malaysia

*Corresponding author: hassanmd@upm.edu.my

\section{Article history}

Received 27 February 2018

Revised 28 March 2018

Accepted 21 May 2018

Published Online 3 September 2018

\begin{abstract}
Probiotics have been widely known to have the ability to improve the immune system of livestock and aquatic animal. The present study was carried out to evaluate the effect of dietary supplementation of Enterococcus hirae UPM01 (E1) and UPM02 (E2) on hematological parameters of juvenile African catfish, Clarias gariepinus during pre- and post-challenge with fish pathogen, Aeromonas hydrophila. The probiotics were previously isolated from vegetable wastes which have been fermented for 7 days. The experimental fish (270 tails) with an average weight of $5.13 \pm 1.03 \mathrm{~g}$ were distributed and divided randomly into 3 groups (Control (CTRL), E1 $\left(10^{8} \mathrm{CFU} / \mathrm{ml}\right)$ and E2 $\left(10^{8} \mathrm{CFU} / \mathrm{ml}\right)$. The feeding trial was conducted for 50 days. All experimental groups were then challenged with A. hydrophila $\left(1.5 \times 10^{6}\right.$ $\mathrm{CFU} / \mathrm{mL}$ ) via intraperitoneal injection on day $51^{\text {st }}$. Prior to challenge, blood samples were collected randomly from five fish from each group on day $51^{\text {st }}$ (pre-challenge). After $72 \mathrm{hrs}$ of post-challenge, blood samples were again collected from five fish from each group. The hematological parameters such as total erythrocyte count (RBC), total leucocyte count (WBC), packed cell volume (PCV), hemoglobin $(\mathrm{Hb})$, mean corpuscular volume (MCV) and corpuscular hemoglobin concentration (MCHC) were examined. Hematological profiles of pre- and post-challenge infected juvenile catfish were compared with the control group. The RBC, Hb, WBC, PCV, MCV and MCHC of fish fed with probiotics showed significant difference $(\mathrm{P}<0.05)$ as compared to control group during pre- and postchallenge of pathogen. The high level of RBC and WBC during pre- and post-challenge showed the capability of the probiotics to improve the immune responses of juvenile African catfish and thus increased the fish disease resistance against $A$. hydrophila infection. The result suggested that both E. hirae UPM01 and UPM02 could be used effectively as a probiotics in aquaculture.
\end{abstract}

Keywords: Probiotics, Enterococcus hirae, Clarias gariepinus, Aeromonas hydrophila, hematological parameters

\section{INTRODUCTION}

In aquaculture, the use of probiotics are much wider than in terrestrial animal. A number of probiotics either as monospecies or multispecies enrichments are accessible commercially for aquaculture usage (Decamp \& Moriarty, 2006; Ghosh et al., 2007). Probiotics defend fish by several mechanisms such as hindering adhesion sites for pathogens, production of organic acids to lower the $\mathrm{pH}$ and change protein structure, production of hydrogen peroxide and reactive oxygen species to destruct enzyme systems in pathogens and by the triggeration of innate and adaptive immune responses to intensify killing of pathogenic agents (Bloch et al., 2013). However, the important criteria of probiotic should be non-pathogenic and non-toxic in order to avoid unwanted side-effects when applied to fish. Studies have shown that probiotics are essential for non-specific immune system triggering (Lara-Flores, 2011; Tran et al., 2017).
African catfish, Clarias gariepinus Burchell, 1822 or locally known as Ikan Keli Afrika in Malaysia belongs to the Clariidae family. It is a native fish species in the African countries and has been introduced and successfully farmed in several countries in Europe (Netherlands, Germany, Belgium), Asian countries (Indonesia, Thailand, Malaysia) and South America (Brazil) (Hepher, 1988). It is highly demanded freshwater food fish and an economically important freshwater fish species all over the world including Malaysia. The predominance is associated with the aquaculture qualities which comprise of the capability of the fish to adapt a different environment and high stocking densities, suitable for monoculture and polyculture with other freshwater fish species, ability to withstand rough handling, high fecundity, fast growth rate and provides inexpensive source of protein with excellent nutritional quality of meat (Grayton \& Beamish, 1977; Hecht et al., 1996; Hogendoorn, 1981; James \& Sampath, 2003; Musefiu et al., 2011; Olatoye \& Basiru, 2013; Thomas et al., 2013). 
Infectious diseases are most common problems in the aquaculture industry, in which bacterial infections are one of the major accountable for economic loss to all fish farmer worldwide (Thomas et al., 2013). Aeromonas hydrophila which causes Motile Aeromonad Septicemia (MAS) is one of the common bacteria that associated with tail and fin rot hemorrhagic septicemia and epizootic ulcerative syndrome (Hecht et al.) in African catfish. The bacteria are known to be indigenous in the aquatic environment (Janda \& Abbott, 2010) therefore they are connected with the fish as normal commensal flora (Janda \& Abbott, 2010; Yardimci \& Aydin, 2011). But the disease is of economic importance as it mainly affects young fish and accounts for epidemic outbreaks which resulting in massive mortality (Ahamad et al., 2013; Haniffa \& Mydeen, 2011). MAS has been associated with skin lesions in naturally diseased fish species cultured in different parts of the world (Ahamad et al., 2013; Alsaphar \& Al-Faragi, 2012; Dias et al., 2012; Shayo et al., 2012; Thomas et al., 2013) including African catfish cultured in Bangladesh (Rahman et al., 2002), India (Hatha et al., 2005), Malaysia (Hayati et al., 2015; Laith \& Najiah, 2013) and Nigeria (Ajayi, 2012; Anyanwu \& Kennedy, 2016).

Hematological features are significant tool that can be applied as an effective guide to examine physiological alteration in the fish Standard ranges for countless blood parameters in fish have been established by different researchers in fish physiology and pathology (Rambhaskar \& Rao, 1987; Zhou et al., 2009). The assessment of blood indices has been demonstrated to be an important tool for analyzing the health status of farmed animals (Bahmani et al., 2001). There are various studies on identification of bacteria from fish, experimental infection of bacterial or disease resistance against the bacterial pathogen (Al-Harbi \& Uddin, 2004; Cai et al., 2004). However, only a few studies relate the hematological parameters to bacterial experimental infection. So, the present study was designed to evaluate the effect of probiotic Enterococcus hirae on hematological parameters of juvenile African catfish (Clarias gariepinus) during pre- and postchallenge against Aeromonas hydrophila.

\section{LITERATURE REVIEW}

\section{Probiotics}

The application of probiotics in aquaculture has been widely used as a mean of strategy for prevention of infectious diseases and to substitute antibiotics and chemotherapeutic. The term probiotic is originally in Greek words meaning "for life" (Gismondo et al., 1999). It was initially used by (Lilly \& Stillwell, 1965) to designate one of the substances produced by protozoans that stimulate other microorganisms. Later, it was used to define animal feed supplements that provide advantage to the host animal (AFRC, 1989). He redefined it as to "a live microbial feed supplement which beneficially affects the host animal by improving its intestinal microbial balance". In 2001, the Food and Agriculture Organization of the United Nations (FAO) and World Health Organization (WHO) Working Group jointly defined probiotics as "live micro-organisms which when administered in adequate amounts confer a health benefit on the host". According to Servin and Coccoiner (2003), probiotic bacteria are considered as nonpathogenic and safe to be used as a food supplementation. In recent years, probiotics have shown to have several modes of action such as competitive elimination of pathogenic bacteria via the production of inhibitory substances, enhance water quality, boost immune response of host species and enrich of nutrient content of host species via the production of additional digestive enzymes (Ayoola et al., 2013; Verschuere et al., 2000).

A major group of probiotic bacteria comes from lactic acid bacteria (LAB) (El-Rhman et al., 2009). The LAB is labeled as Grampositive microorganisms, free from cytochromes and favoring anaerobic conditions, fastidious, acid-tolerant and strictly fermentative, producing lactic acid as the main product. The most important genera of LAB are Lactobacillus, Lactococcus, Enterocococcus, Streptococcus, Pediococcus, Leuconostoc, and Bifidobacterium. Group of LAB are generally divided into two groups; homofermentative and heterofermenative. The groups are based on their carbohydrate metabolism. The homofermentative group consisting of Lactococcus,
Pediococcus, Enterococcus, Streptococcus, and some lactobacilli that utilize the Embden-Meyerhof-Parnas (glycolytic) pathway to transform a carbon source chiefly into lactic acid. Opposed to homofermentors, heterofermentative bacteria produce equimolar amounts of lactate, $\mathrm{CO}_{2}$, ethanol, or acetate from glucose exploiting phosphoketolase pathway. Members of this group include Leuconostoc, Weissella, and some lactobacilli (Vasiljevic \& Shah, 2008).

\section{Control of Aeromonas infection in fishes using probiotics}

$\mathrm{LAB}$ have been used in several aquatic organisms and have been shown to be effective, not only for their capability to prevent disease infection but also for enhancing digestion and growth of the organisms. Most of these studies have been targeted at the early stages of the aquatic organisms, such as the larval and juvenile stages because during this phase, they are more vulnerable to disease infections (Bricknell \& Dalmo, 2005; Dierckens et al., 2009; Fjellheim et al., 2010; Fjellheim et al., 2007; Vine et al., 2006). Therefore the application of probiotics for disease prevention and value-added nutrition in aquaculture industry is becoming popular due to growing demand for environment friendly aquaculture practices (Balcázar et al., 2006).

There were few studies on the control of bacterial infection especially Aeromonas sp. by using probiotics via oral administration. After feeding feed supplemented with Bacillus coagulans and chitosan oligosaccharides, single or combined, the protection effects were increased in koi Cyprinus carpio against A. veronii (Lin et al., 2012). The protection effects against $A$. hydrophila infection in $C$. carpio by bacteria Enterococcus sp. was also observed by Gopalakannan \& Arul (2011). El-Rhman et al. (2009) showed that by feeding Nile tilapia with the Micrococcus luteus, it could provide an inhibitory effect against $A$. hydrophila. Zhou et al. (2010) also observed the capability of Lactococcus lactis to show inhibitory effect against $A$. hydrophila in vitro. Kumar et al. (2006) evaluated the use of Bacillus subtilis in Labeo rohita against $A$. hydrophila infection and found out that the probiotic was effective in controlling the infection. In 2007, Newaj-Fyzul et al. observed that $B$. subtilis could be used to control Aeromonas infection in Rainbow trout. Besides, the in vitro antimicrobial assay of $B$. subtilis and Lactobacillus acidophilus inhibited the growth of A. hydrophila (Aly et al., 2008). They also have found that Tilapia nilotica (Oreochromis niloticus) fed with this bacterial mixture demonstrated better defense mechanism against $A$. hydrophila infection.

\section{Hematological parameters}

Information regarding hematology is most necessary since it deals with the morphology, physiology and the biochemistry of blood. By evaluating blood cell physiognomies, health status can be recognized. However, their fluctuation relies on the fish species, age, the cycle of sexual maturity and health condition (Bielek \& Strauss, 1993; Blaxhall, 1972; Golovina \& Trombicky, 1989; Golovina et al., 1996; Hrubec et al., 2001; Luskova, 1998; Vosyliene, 1999; Wedemeyer et al., 1983; Zhiteneva et al., 1989). In aquaculture, it is important to notice disease and bacterial infection in the early period of the infection. Nevertheless, it is a promising tool for early diagnosis of illnesses by assessing hematological data, mainly blood parameters. Standard ranges for various blood parameters in fish have been proven by different researchers in fish physiology and pathology (Rambhaskar \& Rao, 1987; Zhou et al., 2009) due to its role as the valuable approach for analyzing the health status of farmed animals in the early stage (Bahmani et al., 2001).

Hematological parameters are meticulously correlated to the response of the animal to the environment, a sign that the environment of fish habitat could wield some impact on the hematological features (Gabriel et al., 2004). These indices have been engaged in commendably observing the reactions of fish to the stressors and consequently their health state under such adverse circumstances. They can deliver significant diagnostic info once reference standards are recognized under standardized conditions. Assessment of the hemogram includes the determination of the total erythrocyte count (RBC), total white blood cell count (WBC), hematocrit (PCV), hemoglobin concentration $(\mathrm{Hb})$, erythrocyte indices $(\mathrm{MCV}, \mathrm{MCH}$, $\mathrm{MCHC}$ ), white blood cell differential count and the evaluation of stained peripheral blood films. Hence, the hematological parameters are 
an important tool for diagnosis the status of fish health (Blaxhall, 1972; Martins et al., 2000; Tavares-Dias et al., 2004; Řehulka, 2002) and also as an evidence about their physiology and environmental condition (Ramaswamy \& Reddy, 1978).

\section{METHODOLOGY/MATERIALS}

\section{Isolation and identification of Enterococcus hirae}

Bacteria strains that used in this study were previously isolated from vegetable wastes. Briefly, vegetable wastes were collected from six different retail markets around Selangor, Malaysia. The samples were collected in sterile polythene zip bags to avoid any additional contaminations and transported to the Laboratory of Aquatic Animal Health Unit, Faculty of Veterinary Medicine, Universiti Putra Malaysia for fermentation process (seven days of fermentation period and followed the method according to Pérez-Díaz et al. (2014) with slightly modifications) and microbial analysis were carried out using serial dilution and spread plate method on deMan, Rogosa and Sharpe agar (MRS) plates. After $24 \mathrm{hrs}$ of incubation at $37^{\circ} \mathrm{C}$, different colonies of bacteria were randomly picked from the plates and were preliminary identified using Gram stain and biochemical tests (API 20 STREP, Biomerieux) and further identified using 16S rRNA gene sequence.

The isolates were also tested for their resistance towards several types of physiology conditions such as different range of $\mathrm{pH}(2-8)$, $\mathrm{NaCl}(0-6.5 \%)$ and temperature $\left(4-45{ }^{\circ} \mathrm{C}\right)$ as described by Allameh et al. (2014) with some modifications. Not only that, after physiological screening, the ability of selected probiont to inhibit the growth of Aeromonas hydrophila were done by using dot spot methods according to Schillinger \& Lucked (1989) with slightly modifications. E. hirae UMP01 (waste of fermented cucumber) and UMP02 (waste of fermented mung bean sprouts) that can produce large inhibition zone were chosen for further experiment.

\section{Fish and experimental condition}

Apparently, 270 tails of healthy juvenile African catfish with an average body weight of $5.13 \pm 1.03 \mathrm{~g}$ were obtained from a commercial farm at Selangor, Malaysia. Fish were kept in 1.5 ton tank and maintained in aerated de-chlorinated fresh water at $28.5-29.5^{\circ} \mathrm{C}$ and were acclimatized for a week before they were allotted to the different dietary treatments. Water quality (DO, $\mathrm{pH}$ and temperature) were measured and recorded daily by using YSI Water Quality Meter.

\section{Diets and experimental design}

The experiments were conducted at Aquatic Animal Health Unit, Faculty of Veterinary Medicine, Universiti Putra Malaysia. The catfish were acclimatized and adapted on feeding with the commercial diet (without any additives) to satiation twice a day. After the acclimatization period, 270 fish were divided into 3 groups (Control (CTRL), Enterococcus hirae UPM01 (E1) and E. hirae UPM02 (E2)) and distributed randomly into 300-1 tanks (30 fish per tank) and acclimatized for the experimental conditions for another week prior to the start of the experiment. Water was changed every two days to maintain good water quality. Water quality parameters ( $\mathrm{DO}, \mathrm{pH}$, and temperature) were checked and recorded twice daily throughout the experimental period. The experiment was conducted in three replicates and the fish were fed over a period of 50 days. A non-stop aeration to maintain the dissolved oxygen to the optimal level were provided. All fish were fed twice daily to satiation and dead fish from each tank were collected daily and weighed.

In this experiment, a commercial starter diet was used as a basal diet. Pure culture of E. hirae UPM01 and UPM02 were used for the experimental diet preparation. The isolates were inoculated into sterile MRS broth (Oxoid, UK) and incubated at $37{ }^{\circ} \mathrm{C}$ for $24 \mathrm{hrs}$. The cells were then harvested by centrifugation at 3,000 rpm for $15 \mathrm{~min}$, washed twice and re-suspended in $0.85 \%$ normal saline. The concentration of the cells were checked by using spectrophotometer (OD $600 \mathrm{~nm}$ ) in order to obtain $10^{8} \mathrm{CFU} / \mathrm{ml}$. After that, $100 \mathrm{ml}$ of the cells were thoroughly sprayed and mixed with $1000 \mathrm{~g}$ of commercial fish feed. This procedures were done for both E1 and E2, respectively. For the control feed (CTRL), $100 \mathrm{ml}$ of $0.85 \%$ normal saline was used to mixed with $1000 \mathrm{~g}$ of the commercial fish feed. All experimental feed were let air dried in a plastic container for $30 \mathrm{~min}$, packed in air-tight containers, labeled and stored in the freezer at $15^{\circ} \mathrm{C}$. Supplemented diets were used within a weeks and new batches of diet were prepared using the above procedures.

\section{Challenge assay}

A local isolate of pathogenic strain of A. hydrophila was used in the challenge test was obtained and maintained at the Aquatic Animal Health Unit, Faculty of Veterinary Medicine, Universiti Putra Malaysia, Malaysia. After the end of feeding trial, three replicate tanks (10 fish/tank) of each dietary treatment were challenge via intraperitoneal injection with $0.1 \mathrm{ml}$ of $A$. hydrophila at a concentration of $1.5 \times 10^{6} \mathrm{CFU} / \mathrm{ml}$. The control fish received $0.1 \mathrm{ml}$ of normal saline intraperitoneally. Water were renewed every two days and mortality was recorded every $24 \mathrm{hrs}$ for $72 \mathrm{hrs}$.

\section{Sample of blood collection and analysis}

Blood samples were collected from (three fish from each tank on $51^{\text {st }}$ days (pre-challenge) and after 72 hrs of post-challenge with $A$. hydrophila. Blood was collected from the caudal vein of the fish using a $1 \mathrm{ml}$ syringe attached to $21 \mathrm{G}$ needle after anesthetizing with $50 \mathrm{mg} / \mathrm{l}$ (50ppm) tricaine methane sulfonate (MS-222; Argent Chemical Laboratories) and transferred promptly into tubes containing lithium heparin anticoagulant. Leucocyte counts (TLC) and erythrocyte counts (RBC) were determined manually utilizing a Neubauer hemocyter using Natt-Herrick's stain (1952). Other blood parameters (Hecht et al.) were estimated using an automated blood analyzer (Abbott Cell-Dyn 3700, Abbott laboratories, Abbott Park IL, USA). The hematological parameters were expressed in international units (SI).

\section{Statistical analysis}

Data obtained from the experiment were analyzed using One-way analysis of variance (ANOVA) and significant differences among treatment means were compared using Duncan's multiple range test (Duncan, 1955). Significance was tested at 5\% level and all statistical analyses were carried out using the SPSS.

\section{RESULTS AND FINDINGS}

In Table 1, there were increased in mean values of the hematological parameters of probiotics supplemented group after the feeding experiment. All hematological parameter (i.e. RBC, $\mathrm{Hb}, \mathrm{PCV}$, $\mathrm{MCV}, \mathrm{MCHC}, \mathrm{WBC}$ and Thrombocytes) in group E1 and E2 were significantly $(\mathrm{p}<0.05)$ enhanced as compared to the control group.

In the present study, after challenged with A. hydrophila, all hematological parameter of the supplemented groups (E1 and E2) shown to remain increase as compared to the control group (Table 2). However, the mean values of $\mathrm{RBC}, \mathrm{Hb}, \mathrm{PCV}, \mathrm{MCHC}$ and thrombocytes values of the control group decreased when compared with the supplemented groups (E1 and E2). Conversely, during postchallenge of A. hydrophila, the MCV and WBC values of the control group were increased (Table 2).

Means with the same superscript in rows were not significantly different at $\mathrm{P}<0.05$. Values in parentheses are standard errors of means. $\mathrm{PCV}=$ packed cell volume, $\mathrm{Hb}=$ hemoglobin, $\mathrm{WBC}=$ white blood cell count, $\mathrm{RBC}=$ red blood cell count, $\mathrm{MCV}=$ mean corpuscular volume, $\mathrm{MCHC}=$ mean corpuscular hemoglobin concentration

Table 1 Hematological characteristics of juvenile African catfish fed experimental diets with $E$. hirae pre-challenge with $A$. hydrophila.

\begin{tabular}{cccc}
\hline \multirow{2}{*}{ Parameters } & \multicolumn{3}{c}{ Diets } \\
\cline { 2 - 4 } & CTRL & E2 & E2 \\
\hline $\mathrm{RBC}, \times 10^{12} / \mathrm{L}$ & $2.22 \pm 0.01^{\mathrm{a}}$ & $2.82 \pm 0.02^{\mathrm{b}}$ & $2.46 \pm 0.05^{\mathrm{c}}$ \\
$\mathrm{Hb}, \mathrm{g} / \mathrm{L}$ & $103 \pm 1.53^{\mathrm{a}}$ & $107 \pm 0.58^{\mathrm{c}}$ & $105 \pm 1.00^{\mathrm{b}}$ \\
$\mathrm{PCV}, \mathrm{L} / \mathrm{L}$ & $0.32 \pm 0.01^{\mathrm{a}}$ & $0.33 \pm 0.01^{\mathrm{b}}$ & $0.34 \pm 0.01^{\mathrm{b}}$ \\
$\mathrm{MCV}, \mathrm{fL}$ & $122 \pm 1.72^{\mathrm{a}}$ & $134 \pm 1.00^{\mathrm{b}}$ & $135 \pm 1.00^{\mathrm{b}}$ \\
$\mathrm{MCHC}, \mathrm{g} / \mathrm{L}$ & $322 \pm 1.53^{\mathrm{a}}$ & $330 \pm 0.98^{\mathrm{b}}$ & $331 \pm 0.63^{\mathrm{b}}$ \\
WBC, $\times 10^{9} / \mathrm{L}$ & $0.40 \pm 0.01^{\mathrm{a}}$ & $0.54 \pm 0.01^{\mathrm{b}}$ & $0.86 \pm 0.05^{\mathrm{c}}$ \\
Thrombo, $\mathrm{x} 10^{9} / \mathrm{L}$ & $11.2 \pm 0.06^{\mathrm{a}}$ & $21.50 \pm 0.10^{\mathrm{c}}$ & $15.30 \pm 0.66^{\mathrm{b}}$ \\
\hline
\end{tabular}

${ }^{*}$ Results are means of three determinations \pm SD (standard deviation). 
Table 2 Hematological characteristics of juvenile African catfish fed experimental diets with $E$. hirae post-challenge with $A$. hydrophila.

\begin{tabular}{|c|c|c|c|}
\hline \multirow{2}{*}{ Parameters } & \multicolumn{3}{|c|}{ Diets } \\
\hline & CTRL & E1 & E2 \\
\hline RBC, $\times 10^{12} / \mathrm{L}$ & $2.14 \pm 0.01^{\mathrm{a}}$ & $2.99 \pm 0.01^{\mathrm{b}}$ & $2.69 \pm 0.02^{c}$ \\
\hline $\mathrm{Hb}, \mathrm{g} / \mathrm{L}$ & $101 \pm 0.58^{a}$ & $110 \pm 0.58^{c}$ & $107 \pm 1.00^{\mathrm{b}}$ \\
\hline PCV, L/L & $0.31 \pm 0.01^{\mathrm{a}}$ & $0.39 \pm 0.01^{\mathrm{c}}$ & $0.37 \pm 0.01^{b}$ \\
\hline$M C V, f L$ & $130 \pm 2.00^{a}$ & $139 \pm 1.31^{\mathrm{b}}$ & $138 \pm 1.04^{b}$ \\
\hline $\mathrm{MCHC}, \mathrm{g} / \mathrm{L}$ & $317 \pm 0.45^{a}$ & $342 \pm 0.58^{b}$ & $344 \pm 2.12^{c}$ \\
\hline WBC, $\times 10^{9} / \mathrm{L}$ & $0.45 \pm 0.01^{\mathrm{a}}$ & $0.63 \pm 0.01^{b}$ & $0.91 \pm 0.05^{c}$ \\
\hline Thrombo, $x 10^{9} / \mathrm{L}$ & $10.60 \pm 0.06^{a}$ & $23.3 \pm 0.42^{\mathrm{c}}$ & $16.5 \pm 0.61^{b}$ \\
\hline
\end{tabular}

The hematological results of the present study showed that RBC, $\mathrm{Hb}, \mathrm{WBC}, \mathrm{PCV}, \mathrm{MCV}$ and MCHC of fish fed with E1 and E2 showed significantly elevated $(\mathrm{P}<0.05)$ compared to control group. The increased in RBC levels, reflected the increases in derived indices by the production of young and immature RBCs with high $\mathrm{Hb}$ content. Ologhobo (1992) reported that the most common blood characteristics that consistently influenced by diet are the RBC and $\mathrm{Hb}$ levels. Hence, fish fed with diet supplemented E1 and E2 might have stimulated the increasing of $\mathrm{RBC}$ and $\mathrm{Hb}$ values.

During post-challenge of A. hydrophila, the mean values of RBC, $\mathrm{Hb}, \mathrm{WBC}, \mathrm{PCV}, \mathrm{MCV}$ and MCHC of fish fed with diet supplemented $\mathrm{E} 1$ and $\mathrm{E} 2$ remain significantly higher $(\mathrm{p}<0.05)$ as compared to control group. On the other hand, in the control group, the mean values of RBC, $\mathrm{Hb}, \mathrm{PCV}, \mathrm{MCHC}$, and thrombocytes showed a decreased values compared to during pre-challenge of $A$. hydrophila. The decreased in hemoglobin values might be due to the swelling of the $\mathrm{RBC}$ along with deprived mobilization of hemoglobin from the spleen to other hematopoietic organs (Scott \& Rogers, 1981). This study also supported the current report that stated the significant decrease in RBC and hemoglobin content was probably due to hypochromic microcytic anemia triggered by A. hydrophila infection (Kumar \& Ramulu, 2013). Decreased of RBC counts, PCV and hemoglobin concentration also pointed out that RBCs were being destroyed by the leucocytosis activity in an erythrocytic anemia following erythroblastosis (Haney et al., 1992). Current results are in agreement with a study by Marzouk et al., (2008) that showed increases in RBCs count, HB value, PCV and WBCs count in Nile tilapia fed with diet supplemented with probiotic (B. subtillis and Saccharomyces cerevisae).

In the present study, during post-challenge, increased in MCV was observed not only in the in fish supplemented with E1 and E2 but also in the control group. This phenomenon could be as a result of the erythrocytes swelling, which occurred in a macrocytic anemia condition. According to Tort \& Torres (1988), macrocytic anemia in fish occur when exposed to stress; increases the affinity for oxygen in the blood (Soivio \& Nikinmaa, 1981). The decrease level of MCHC was also seen in control group. This undoubtedly showed that the concentration of $\mathrm{Hb}$ in the RBC was much lower in the control group than in the treatment groups (E1 and E2), thus demonstrating an anemic condition. A significant decreased in the MCHC during post-challenge of control group could be a sign of RBCs swelling or a diminution in hemoglobin synthesis. The increase in MCV and the reduction in MCHC concentration in the infected catfish with A. hydrophila were similar to finding by Kumar et al. (2013). The significant increase of RBC indices such as MCV and MCHC in the fish fed with supplemented probiotics diets during pre- and post-challenge suggested that the probiotics used in this study as feed supplement has increased the blood parameter values by hematopoietic stimulation (Renuka et $a l ., 2014)$. It was also indicated that the concentration of $\mathrm{Hb}$ in the RBCs were much higher in the fish fed supplemented $E$. hirae than in the control group, thus anemic condition was prevented.

WBCs is very important characteristics of the health state of fish and in many cases, they are helpful in evaluating the fish immune system. The level of WBCs in the hematological characteristic of fish is very dependent on several reasons and one of them is nutrition (Golovina et al., 1996; Svobodova et al., 1998). In the present study, the WBC levels showed enhanced when fed with diets containing $E$. hirae probiotics. This condition gave a positive role in improving juvenile African catfish immunity against $A$. hydrophila when levels of WBC were observed to increase during post-challenge. Thrombocytes on the other hand, is considered as one of the defense blood cells and were said to be involved in the organic defense mechanism (Martins et al., 2004; Penha et al., 1996). When the mechanism of organic protection is disturbed, the cells involved in defense cells will consist of leucocytes as well as thrombocytes (Tavares-Dias et al., 2000). This theory is said to be centered on the pathology parts but not on the physiological ones. Parallel to the present study, the abundance of thrombocytes in blood of healthy fish were observed by a number of authors (LeaMaster et al.,1990; Murray, 1984; Tavares-Dias et al., 2000).

\section{CONCLUSION}

In conclusion, the E. hirae UPM01 and UPM02 have shown significantly improve hematological parameters in juvenile African catfish during pre- and post-challenge with A. hydrophila. Present results suggested that the probiotics supplementation feed were responsible for maintaining the hematological variables to normal condition and further increased the activation of the innate immune responses of African catfish against $A$. hydrophila when supplemented with $1.0 \times 10^{8} \mathrm{CFU} / \mathrm{ml}$ of $E$. hirae UPM01 and UPM02. The results also indicated that both $E$. hirae proved to be a good candidate of probiotics tool which may be applied for aquaculture practices when supplemented according to a suitable concentration in order to prevent the anemic condition.

\section{ACKNOWLEDGEMENT}

The authors would like to thanks The Knowledge Transfer Programme Grant Scheme, MyBrain and SEARCA scholarship for financial support to conduct the research.

\section{REFERENCES}

Ahamad, B., Punniamurthy, D., Kumar, N. S., Malmarugan, V., Suresh, R., Ranganathan, V. 2013. Outbreak of bacterial haemorrhagic septicaemia in freshwater carps in thanjavur region of tamil nadu. Paper presented at the Proceedings of the national seminar on current perspectives in Biological Sciences (NSOCPIBS-2012).

Ajayi, A. O. 2012. Bacteriological study of catfish, Claria gariepinus, from fish pond sources in Akungba-Akoko community, Nigeria. British Microbiology Research Journal, 2, 1, 1-9.

Al-Harbi, A. H., Uddin, M. N. 2004. Seasonal variation in the intestinal bacterial flora of hybrid tilapia (Oreochromis niloticus $\times$ Oreochromis aureus) cultured in earthen ponds in Saudi Arabia. Aquaculture, 229, 1-4, 37-44.

Allameh, S.K., Ring $\varnothing$, E., Yusoff, F.M., Daud, H.M. and Ideris, A. 2014. Properties of Enterococcus faecalis, a new probiotic bacterium isolated from the intestine of snakehead fish (Channa striatus, Bloch). African Journal of Microbiology Research, 8, 2215-2222.

Alsaphar, S. A. A., Al-Faragi, J. K. H. 2012. Detection and study of the experimental infection of Aeromonas strain in the common carp (Cyprinus carpio L.). The Iraqi Journal of Veterinary Medicine, 36, 2, 222-230.

Aly, S. M., Ahmed, Y. A.-G., Ghareeb, A. A.-A., Mohamed, M. F. 2008. Studies on Bacillus subtilis and Lactobacillus acidophilus, as potential probiotics, on the immune response and resistance of Tilapia nilotica (Oreochromis niloticus) to challenge infections. Fish \& Shellfish Immunology, 25, 1-2, 128136.

Anyanwu, M. U., Chah, K. F. 2016. Antibacterial resistance in African catfish aquaculture: A review. Notulae Scientia Biologicae, 8, 1, 1-20.

Ayoola, S. O., Ajani, E. K., Fashae, O. F. 2013. Effect of probiotics (Lactobacillus and Bifidobacterium) on growth performance and hematological profile of Clarias gariepinus juveniles. World Journal of Fish and Marine Sciences, 5, 1, 1-8.

Bahmani, M., Kazemi, R., Donskaya, P. 2001. A comparative study of some hematological features in young reared sturgeons (Acipenser persicus and Huso huso). Fish Physiology and Biochemistry, 24, 2, 135-140.

Balcázar, J. L., de Blas, I., Ruiz-Zarzuela, I., Cunningham, D., Vendrell, D., Muzquiz, J. L. 2006. The role of probiotics in aquaculture. Veterinary Microbiology, 114, 3, 173-186. 
Bielek, E., Strauss, B. 1993. Ultrastructure of the granulocytes of the South American lungfish, Lepidosiren paradoxa: Morphogenesis and comparison to other leucocytes. Journal of Morphology, 218, 1, 29-41.

Blaxhall, P. C. 1972. The haematological assessment of the health of freshwater fish. Journal of fish biology, 4, 4, 593-604.

Bloch, E. F., Schultz, R. D., Turner, W. 2013. Mini-review: Probiotics and disease prevention in different host systems. British Microbiology Research Journal, 3, 1, 42-571.

Bricknell, I., Dalmo, R. A. 2005. The use of immunostimulants in fish larval aquaculture. Fish \& Shellfish Immunology, 19, 5, 457-472.

Cai, W. Q., Li, S. F., Ma, J. Y. 2004. Diseases resistance of Nile tilapia (Oreochromis niloticus), blue tilapia (Oreochromis aureus) and their hybrid (female nile tilapia $\times$ male blue tilapia) to aeromonas sobria. Aquaculture, 229 1-4, 79-87.

Decamp, O., Moriarty, D. J. W. 2006. Probiotics as alternative to antimicrobials: Limitations and potential. World Aquaculture, 37, 4, 60-62.

Dias, C., Mota, V., Martinez-Murcia, A., Saavedra, M. J. 2012. Antimicrobial resistance patterns of Aeromonas spp. isolated from ornamental fish. Journal of Aquaculture \& Research Development, 3, 3: 1000131.

Dierckens, K., Rekecki, A., Laureau, S., Sorgeloos, P., Boon, N., Van Den Broeck, W., Bossier, P. 2009. Development of a bacterial challenge test for gnotobiotic sea bass (Dicentrarchus labrax) larvae. Environmental Microbiology, 11, 2, 526-533.

Duncan, D. B. 1955. Multiple range and multiple F tests. Biometrics, 11, 1, 142.

El-Rhman, A. M. A., Khattab, Y. A. E., Shalaby, A. M. E. 2009. Micrococcus luteus and Pseudomonas species as probiotics for promoting the growth performance and health of Nile tilapia, Oreochromis niloticus. Fish \& Shellfish Immunology, 27, 2, 175-180.

Fjellheim, A. J., Klinkenberg, G., Skjermo, J., Aasen, I. M., Vadstein, O. 2010 Selection of candidate probionts by two different screening strategies from Atlantic cod (Gadus morhua L.) larvae. Veterinary Microbiology, 144, 1-2, 153-159.

Fjellheim, A. J., Playfoot, K. J., Skjermo, J., Vadstein, O. 2007. Vibrionaceae dominates the microflora antagonistic towards Listonella anguillarum in the intestine of cultured Atlantic cod (Gadus morhua L.) larvae. Aquaculture, 269, 1-4, 98-106.

Fuller, R. 1989. Probiotics in man and animals. Journal of Applied Bacteriology, 66, 5, 365-378.

Gabriel, U. U., Ezeri, G. N. O., Opabunmi, O. O. 2004. Influence of sex, source, health status and acclimation on the haematology of Clarias gariepinus (Burch, 1822). African Journal of Biotechnology, 3, 9, 463-467.

Ghosh, S., Sinha, A., Sahu, C. 2007. Isolation of putative probionts from the intestines of Indian major carps. The Israeli Journal of Aquaculture Bamidgeh, 59, 3, 127-132

Gismondo, M. R., Drago, L., Lombardi, A. 1999. Review of probiotics available to modify gastrointestinal flora. International Journal of Antimicrobial Agents, 12, 4, 287-292.

Golovina, N. A., Trombicky, I. D. 1989. Haematology of pond fish. Kishinev, Shtiinca, p. 158.

Golovina, V. A., Bambrick, L. L., Yarowsky, P. J., Krueger, B. K., Blaustein, M. P. 1996. Modulation of two functionally distinct $\mathrm{Ca}^{2+}$ stores in astrocytes: Role of the plasmalemmal Na/Ca exchanger. GLIA, 16, 4, 296-305.

Gopalakannan, A., Arul, V. 2011. Inhibitory activity of probiotic Enterococcus faecium MC13 against Aeromonas hydrophila confers protection agains hemorrhagic septicemia in common Carp cyprinuscarpio. Aquaculture International, 19, 5, 973-985.

Grayton, B. D., Beamish, F. W. H. 1977. Effects of feeding frequency on food intake, growth and body composition of rainbow trout (Salmo gairdneri). Aquaculture, 11, 2, 159-172.

Haney, D. C., Hursh, D. A., Mix, M. C., Winton, J. R. 1992. Physiological and hematological changes in Chum Salmon artificially infected with Erythrocytic necrosis virus. Journal of Aquatic Animal Health, 4, 1, 48-57.

Haniffa, M. A., Mydeen, K. P. A. K. 2011. Hematological changes in Channa striatus experimentally infected by Aeromonas hydrophila. Bioresearch Bulletin, 4, 250-257.

Hatha, M., Vivekanandhan, A. A., Joice, G. J., Christol. 2005. Antibiotic resistance pattern of motile aeromonads from farm raised fresh water fish. International Journal of Food Microbiology, 98, 2, 131-134.

Hecht, T., Oellermann, L., Verheust, L. 1996. Perspectives on clariid catfish culture in Africa. Aquatic Living Resources, 9, S1, 197-206.

Hepher, B. 1988. Nutrition of pond fishes: Cambridge University Press.

Hogendoorn, H. 1981. Controlled propagation of the African catfish, Clarias lazera (C. \& V.): IV. Effect of feeding regime in fingerling culture. Aquaculture, 24, 123-131.

Hrubec, T. C., Smith, S. A., Robertson, J. L. 2001. Age-related changes in hematology and plasma chemistry values of hybrid striped bass (Morone chrysops $\times$ Morone saxatilis). Veterinary Clinical Pathology, 30, 1, 8-15.
James, R., Sampath, K. 2003. Effects of meal frequency on growth and reproduction in the ornamental red swordtail, Xiphophorus helleri. The Israeli Journal of Aquaculture - Bamidgeh, 55, 3, 197-207.

Janda, J. M., Abbott, S. L. 2010. The genus aeromonas: Taxonomy, pathogenicity, and infection. Clinical Microbiology Reviews, 23, 1, 35-73.

Kumar, M. P., Ramulu, K. S. 2013. Haematological changes in Pangasius hypophthalmus infected with Aeromonas hydrophila. International Journal of Food, Agriculture and Veterinary Sciences, 3, 1, 70-75.

Kumar, R., Mukherjee, S. C., Prasad, K. P., Pal, A. K. 2006. Evaluation of Bacillus subtilis as a probiotic to Indian major carp Labeo rohita (Ham.). Aquaculture Research, 37, 12, 1215-1221.

Laith, A. R., Najiah, M. 2013. Aeromonas hydrophila: Antimicrobial susceptibility and histopathology of isolates from diseased catfish, Clarias gariepinus (Burchell). Journal of Aquaculture Research and Development, 5: 215.

Lara-Flores, M. 2011. The use of probiotic in aquaculture: An overview. International Research Journal of Microbiology, 2, 12, 471-478.

LeaMaster, B. R., Brock, J. A., Fujioka, R. S., Nakamura, R. M. 1990. Hematologic and blood chemistry values for Sarotherodon melanotheron and a red hybrid tilapia in freshwater and seawater. Comparative Biochemistry and Physiology Part A: Physiology, 97, 4, 525-529.

Lilly, D. M., Stillwell, R. H. 1965. Probiotics: Growth-promoting factors produced by microorganisms. Science, 147, 3659, 747-748.

Lin, S., Mao, S., Guan, Y., Luo, L., Luo, L., Pan, Y. 2012. Effects of dietary chitosan oligosaccharides and Bacillus coagulans on the growth, innate immunity and resistance of koi (Cyprinus carpio koi). Aquaculture, 342-343, 36-41.

Luskova, V. 1998. Factors affecting hematological indices in free-living fish populations. Acta Veterinaria Brno, 67, 4, 249-255.

Martins, M. L., Tavares-Dias, M., Fujimoto, R. Y., Onaka, E. M., Nomura, D. T. 2004. Haematological alterations of Leporinus macrocephalus (Osteichtyes: Anostomidae) naturally infected by Goezia leporini (Nematoda: Anisakidae) in fish pond. Arquivo Brasileiro de Medicina Veterinária e Zootecnia, 56, 5, 640-646.

Marzouk, M. S., Moustafa, M. M., Nermeen, M. M. 2008. The influence of some probiotics on the growth performance and intestinal microbial flora of $O$. niloticus, 8th International Symposium on Tilapia in Aquaculture, Cairo, Egypt, pp. 1059-1071.

Murray, S. A. 1984. Hematological study of the bluegill, Lepomis macrochirus Raf. Comparative Biochemistry and Physiology Part A: Physiology, 78, 4, 787-791.

Musefiu, T. A., Obuko, E. B., Bolarinwa, A. O. 2011. Isolation and identification of aerobic bacteria flora of the skin and stomach of wild and cultured Clarias gariepinus and Oreochromis niloticus from Ibadan, Southwest Nigeria. Journal of Applied Sciences Research, 7, 7, 1047-1051.

Newaj-Fyzul, A., Adesiyun, A. A., Mutani, A., Ramsubhag, A., Brunt, J., Austin, B. 2007. Bacillus subtilis AB1 controls Aeromonas infection in rainbow trout (Oncorhynchus mykiss, Walbaum). Journal of Applied Microbiology, 103, 5, 1699-1706.

Olatoye, I. O., Basiru, A. 2013. Antibiotic usage and oxytetracycline residue in African catfish (Clarias gariepinus) in Ibadan, Nigeria. World Journal of Fish and Marine Sciences, 5, 3, 302-309.

Ologhobo, A. D. 1992. Nutritive values of some tropical (West African) legumes for poultry. Journal of Applied Animal Research, 2, 2, 93-104.

Penha, M. D. L., Dias, J. L. C., Malucelli, B. E. 1996. Influence of low environmental tem perature on the phagocyticactivity of bullfrog (Rana catesbeiana) thrombocytes. Brazilian Journal of Veterinary Research and Animal Science, 33, 1, 15-18.

Pérez-Diaz, I.M., Breidt, F., Buescher, R.W., Arroyo-López, F.N., JiménezDíaz, R., Garrido Fernández, A., Bautista Gallego, J., Yoon, S. and Johanningsmeier, S.D. 2014. Chapter 51: Fermented and Acidified Vegetables. In: Pouch Downes, F. Ito, K.A. (Eds). Compendium of Methods for the Microbiological Examination of Foods, fifth edition. American Public Health Association, Washington, DC.

Rahman, M., Colque-Navarro, P., Kühn, I., Huys, G., Swings, J., Möllby, R. 2002. Identification and characterization of pathogenic Aeromonas veroni biovar sobria associated with epizootic ulcerative syndrome in fish in Bangladesh. Applied and Environmental Microbiology, 68, 2, 650-655.

Ramaswamy, M., Reddy, T. G. 1978. A comparative study of hematology of three air-breathing fishes. Proceedings of the Indian Academy of SciencesSection B, Animal Sciences, 87, 12, 381-385.

Rambhaskar, B., Rao, S. K. 1987. Comparative haematology of ten species of marine fish from Visakhapatnam Coast. Journal of Fish Biology, 30, 1, 59-66.

Řehulka, J. 2002. Aeromonas causes severe skin lesions in rainbow trout (Oncorhynchus mykiss): Clinical pathology, haematology, and biochemistry. Acta Veterinaria Brno, 71, 3, 351-360.

Renuka, K. P., Venkateshwarlu, M., Naik, A. T. R. 2014. Effect of probiotic (Lactobacillus acidophilus) on haematological parameters of Catla catla (Hamilton). International Journal of Current Microbiology and Applied Sciences, 3, 8, 326-335. 
Ruhil Hayati, H., Hassan, M. D., Ong, B. L., Abdelhadi, Y. M., Nur Hidayahanum, H., Sharifah, R. M., et al. 2015. Virulence genes detection of Aeromonas hydrophila originated from diseased freshwater fishes. Advances in Environmental Biology, 9, 22 S3, 22-26.

Scott, A. L., Rogers, W. A. 1981. Haematological effects of prolonged sublethal hypoxia on channel catfish Ictalurus punctatus (Rafinesque). Journal of Fish Biology, 18, 5, 591-601.

Schillinger, U., Lucke, F.K. 1989. Antibacterial activity of Lactobacillus sake isolated from meat. Applied and Environment Microbiology, 55, 1901-6.

Shayo, S. D., Mwita, C. J., Hosea, K. 2012. Ulcerative Aeromonas infections in tilapia (Cichlidae: Tilapiini) from Mtera Hydropower Dam, Tanzania. Scientific Reports, 1, 1, 115

Soivio, A., Nikinmaa, M. 1981. Swelling of erythrocytes in relation to the oxygen affinity of the blood of the rainbow trout, Salmo gairdneri Richardson In Pickering, A. D. (Ed.). Stress and Fish. (pp.103-119). London: Academic Press.

Svobodova, Z., Kolářová, J., Modra, H., Vajcova, V., Hamáčková, J., Kouřil, J., Kozák, J. K. 1998. Values of haematological indices of wels (Silurus glanis L.) in relationship to the level of nutrition during the pre-spawning period. Acta Veterinaria Brno, 67, 4, 235-242.

Tavares-Dias, M., Schalch, S. H. C., Martins, M. L., Onaka, E. M., Moraes, F. R. 2000. Haematological characteristics of Brazilian Teleosts: III. Parameters of the hybrid tambacu (Piaractus mesopotamicus Holmberg x Colossoma macropomum Cuvier) (Osteichthyes, Characidae). Revista Brasileira de Zoologia, 17, 4, 899-906.

Thomas, J., Madan, N., Nambi, K. S. N., Majeed, S. A., Basha, A. N., Hameed, A. S. S. 2013. Studies on ulcerative disease caused by Aeromonas caviae-like bacterium in indian catfish, Clarias batrachus (Linn). Aquaculture, 376-379, 146-150.

Tort, L., Torres, P. 1988. The effects of sublethal concentrations of cadmium on haematological parameters in the dogfish, Scyliorhinus canicula. Journal of Fish Biology, 32, 2, 277-282.
Tran, N. T., Wang, G. T., Wu, S. G. 2017. A review of intestinal microbes in grass carp Ctenopharyngodon idellus (Valenciennes). Aquaculture Research. 48, 7, 3287-3297

Vasiljevic, T., Shah, N. P. 2008. Probiotics-from Metchnikoff to bioactives. International Dairy Journal, 18, 7, 714-728.

Verschuere, L., Rombaut, G., Sorgeloos, P., Verstraete, W. 2000. Probiotic bacteria as biological control agents in aquaculture. Microbiology and Molecular Biology Reviews, 64, 4, 655-671.

Vine, N. G., Leukes, W. D., Kaiser, H. 2006. Probiotics in marine larviculture. FEMS Microbiology Reviews, 30, 3, 404-427.

Vosyliene, M. Z. 1999. The effect of heavy metals on haematological indices of fish (survey). Acta Zoologica Lituanica, 9, 2, 76-82.

Wedemeyer, G. A., Gould, R. W., Yasutake, W. T. 1983. Some potentials and limits of the leucocrit test as a fish health assessment method. Journal of Fish Biology, 23, 6, 711-716.

Yardimci, B., Aydin, Y. 2011. Pathological findings of experimental Aeromonas hydrophila infection in Nile tilapia (Oreochromis niloticus). Ankara Üniversitesi Veteriner Fakültesi Dergisi, 58, 47-54.

Zhiteneva, L., Poltavceva, T. G., Rudnickaja, O. A. 1989. Atlas of normal and pathological cells in the blood of fish. Rostou-on Don, Rio de Janeiro, Brazil, pp. 112.

Zhou, X., Li, M., Abbas, K., Wang, W. 2009. Comparison of haematology and serum biochemistry of cultured and wild Dojo loach Misgurnus anguillicaudatus. Fish Physiology and Biochemistry, 35, 3, 435-441.

Zhou, X., Wang, Y., Yao, J., Li, W. 2010. Inhibition ability of probiotic, Lactococcus lactis, against $A$. hydrophila and study of its immunostimulatory effect in tilapia (Oreochromis niloticus). International Journal of Engineering, Science and Technology, 2, 7, 73-80. 